NASA Technical Memorandum 89919

\title{
Microstrip Antenna Array With Parasitic Elements
}

(HASA-TH-89919) AICRCSTRIP ABTENAA ARBAY WITH PARASITIC ELEHENTS (NASA) 6 p AVail:

NIIS HC 102/4R 101 CSCI 20N

N87-22089

$\begin{array}{ll}\text { Unclas } \\ \text { H1/32 } & 0074232\end{array}$

Kai F. Lee

The University of Akron

Akron, Ohio

and

Roberto J. Acosta and Richard Q. Lee

Lewis Research Center

Cleveland, Ohio

Prepared for the

1987 AP-S International Symposium

sponsored by the Institute of Electrical and Electronics Engineers

Blacksburg, Virginia, June 15-17, 1987 


\section{MICROSTRIP ANTENNA ARRAY WIIH PNKASITIC ELEMINTS \\ Kai F. Lee \\ Department of Electrical Engineering The University of Akron, Akron, $\mathrm{OH} 44325$ \\ Roberto J. Acosta and Richard Q. Lee NASA Lewis Research Center Cleveland, $\mathrm{OH} \quad 44135$}

\section{INTRODUCTION}

This paper discusses the design of a large microstrip antenna array in terms of subarrays consisting of one fed patch and several parasitic patches. The potential advantages of this design are discussed. Theoretical radiation patterns of a subarray in the configuration of a cross are presented.

\section{DESCRIPTION OF THE IDEA}

In order to obtain the high gain required in many applications, particularly in satellite commuications, antenna arrays with large number of elements are required. This poses several problems if inicrostrip antenna elements are uscd. First, if each clement is connected to a feed line, the resulting feeding network will introduce unwanted radiation as well as copper losses. Second, for a phase array, each individual element will require a phase shifter in order for tine beam to be steered, with the result that a great number of phase shifters are needed in large arrays. For the next generation of satellite communication antennas in which MMIC (monolithic microwave integrated circuit) devices at 20 and $30 \mathrm{GHz}$ are cmployed in array feeds, the cost of the phase shifters is likely to be prohibitive.

The above-mentioned problems will be reduced if the array is divided into subarrays. We propose that the subarray be consisting of one fed patch only, with several closely spaced parasitic patches around it. line parasitic patches derive their energies from near field coupling with the fed element. An example of the subarray configuration is shown in Fig. 1 , consisting of $3 \times 3=9$ rectangular patches. $A$ lincar array of 4 such subarrays is shown in lig. 3 . Uther subarray configurations are of course possible; that of the cross is shown in Fig. 2.

Note in lig. 3 that, although there are 36 patches, only 4 are directly fed and only these 4 will be linked to a phase shifter in a phase array application. 'This arrangement offers the lollowing potential advantages:

(1) Compared to the conventional armagencnt in which every pateh is fed, the number of piase shilters will be roduced by a factor which is equal to the mimlere of patches in the subarray (9) in the eximple. 
shown in Fig. 1).

(2) There will be much less interconnecting lines and hence the heat loss as well as unwanted radiation will be reduced.

(3) The parasitic elements have the effect of widening the bandwidth, with the result that the array will have a larger bandwidth than the case when each patch is fed.

(4) These arrays are relatively simple to manufacture.

In the literature, the idea that parasitic elements can obtain their energies from a nearby fed patch and function as radiating elements in an array was demonstrated experimentally in [1]. More recent experimental work also showed that parasitic patches can enhance the gain [2]. However, the idea of designing a large array in terms of subarrays with parasitic microstrip patches appears to be new. Moreover, there is no theory in the literature on such subarrays. We have undertaken a theoretical analysis of the problem and some results for the cross-type configuration of Fig. 2 are presented below.

\section{THEORETICAL PATTERN OF THE CROSS-TYPE SUBARRAY}

In our theoretical model of the 5-element cross-type subarray, the patches are assumed to have the same dimensions and are treated as resonators of the same frequency. The fed patch is excited by the coax located at $\left(x^{\prime}, y^{\prime}\right)$ at the resonant frequency corresponding to the $T M_{10}$ mode. The side walls of the patch are assumed to be perfect magnetic walls, the magnetic currents on which are calculated by the cavity model [3]. The parasitic patches are excited by radiative coupling from the magnetic current on the adjacent edge of the fed patch. This near field coupling determines the amplitudes and phases of the magnetic currents on the side walls of the parasitic patches. The far-field of the antenna is obtained by suming the contributions from the fed and parasitic elements.

Fig. 4 shows the far-field patterns in the $\emptyset=0$ plane for a 5element cross with a resonant frequency of $13.8 \mathrm{Gliz}$ for the $\mathrm{TM}_{10}$ mode. The aspect ratio $a / b=1.5$ and the substrate thickness $t=0.04 \lambda$ where $\lambda$ is the free space wavelength. Results for two spacings are shown? For conparison purposes, the pattern of a single patch is also included. It is is seen that the parasitic elements increase the directional property of the antenna. Moreover, tine field strength at broadside is found to be enhanced by the parasitic elements. It is $6 \mathrm{db}$ stronger when $d / \lambda=0.1$ and $10 \mathrm{db}$ stronger when $d / \lambda_{0}=0.05$. Similar results are obtained in the $\emptyset=90^{\circ}$ plane.

\section{CONCLUSION}

In conclusion, the idea of designing microstrip antenna arrays in temis of subarrays with parasitic patches has been discussed. A theoretical model of a subarray in the form of a cross shows that 
enhancement of the directivity is obtained by using close spacing between the fed and the parasitic elements. Theoretical and experimental work are continuing.

\section{REFLRJNCLS}

1. H. Entschladen and U. Nagel, "Microstrip Patch Array Antenna", Electronics Lett. Vol. 20, pp. 931-933, 1984.

2. P.S. Bhatnagar, J.P. Daniel, K. Mahdjoubi, and C.Terret, "Hybrid Edge, Gap and Directly Coupled Triangular Microstrip Antenna", Electronics Lett. Vol. 22, pp. 853-855, 1986.

3. Y.T. Lo, D. Solomon, and W. F. Richards, "lheory and Experiment on Microstrip Antennas", IEEE Trans. Ant. \& Prop. Vol. AP-27, 137-145, 1979.

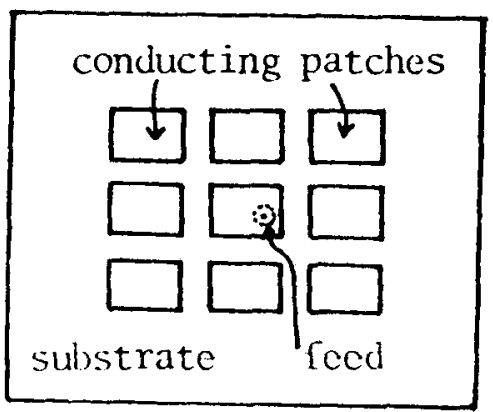

Fig. 1 A $5 \times \overline{3}$ Subarray of rectangular microstrip patches. Only the conter patch is fed.

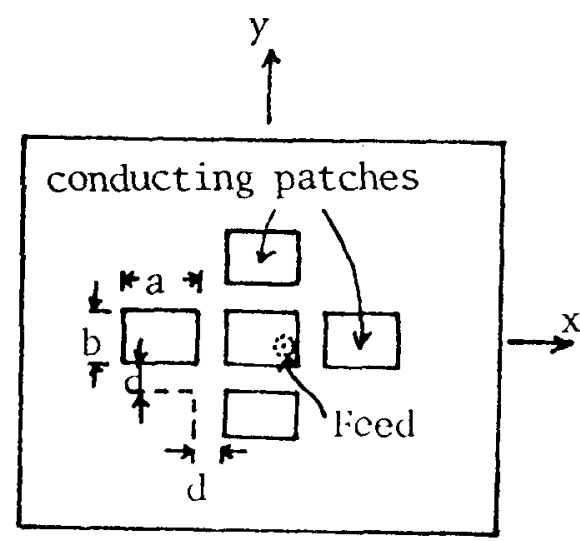

Fig. 2 A subarray in the foril of a 5 -element cross. Only the center patch is fed.

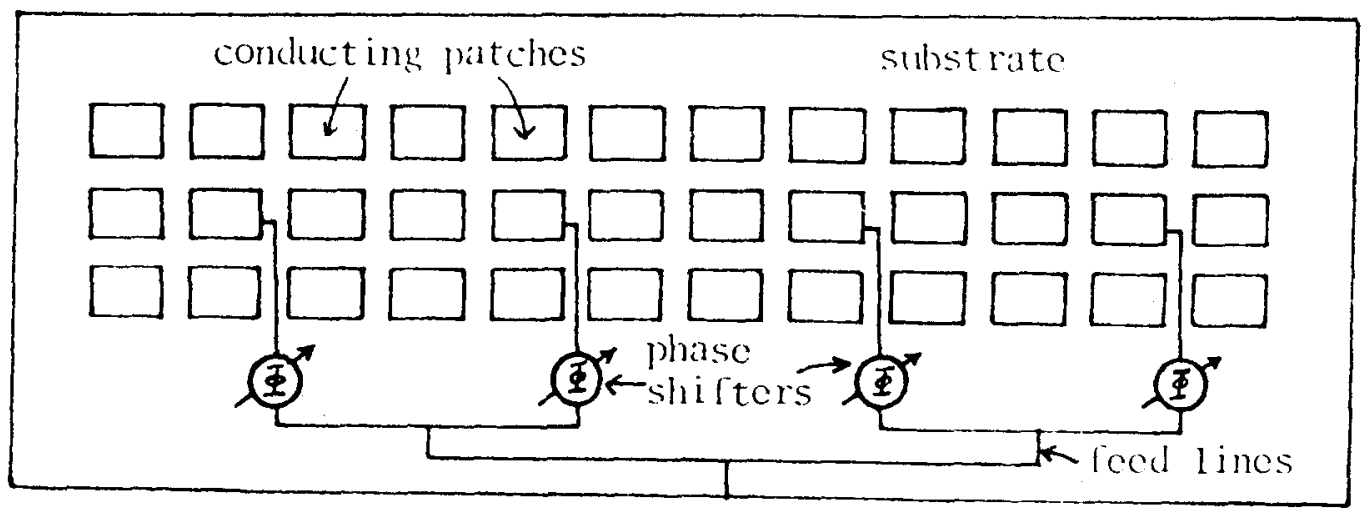

lig. 5 i lincar array consisting of 4 subarrays. lach subaray hats one fed patch and eight parasitic patches. 


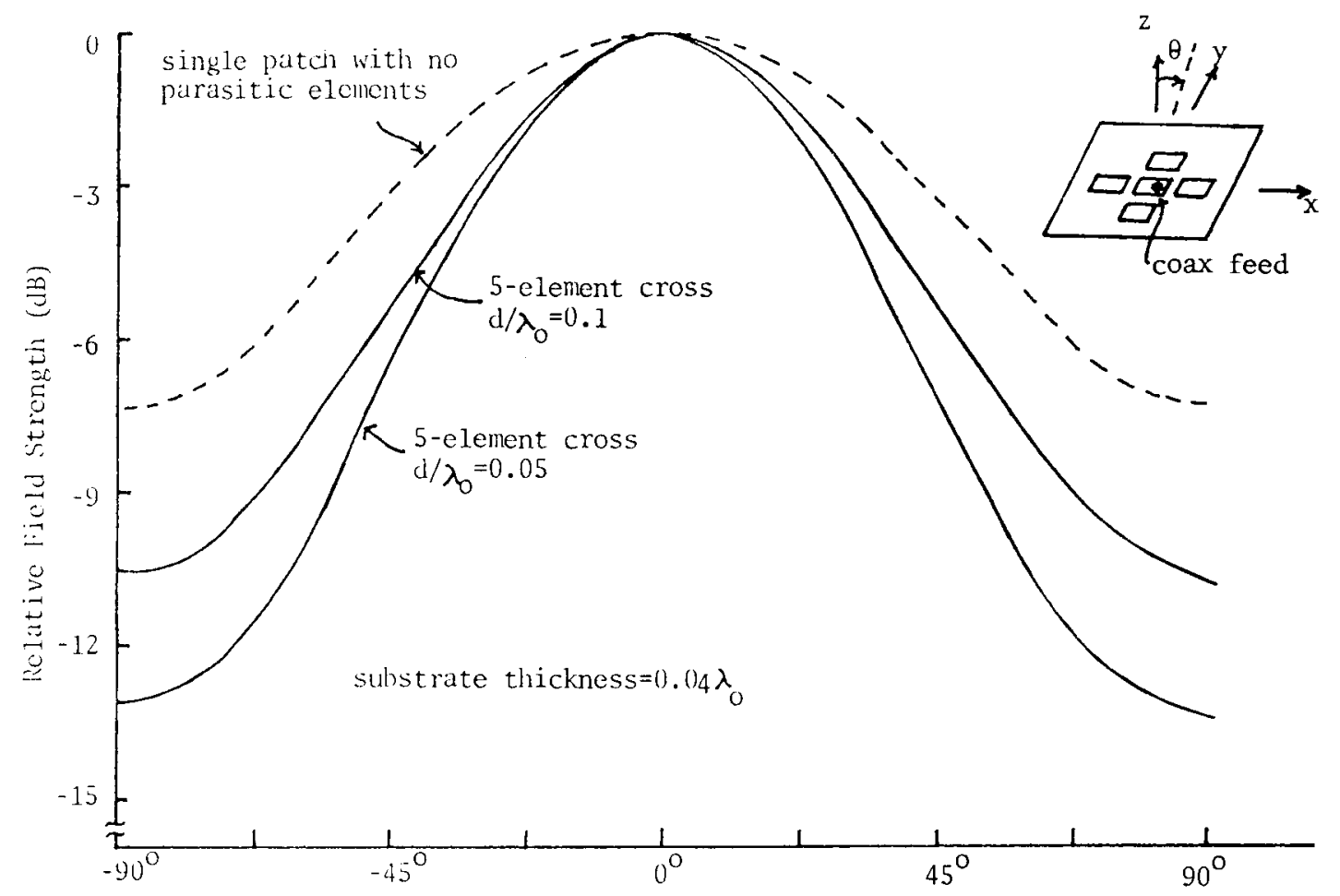

I:ig. 4 Relative ficld strength in the $\theta=0^{\circ}$ plane of a 5 -element cross-type subirray with a coax-fed center elelient. 


\begin{tabular}{|c|c|c|}
\hline $\begin{array}{l}\text { 1. Report No. } \\
\text { NASA TM-89979 }\end{array}$ & 2. Government Accession No. & 3. Recipient's Catalog No. \\
\hline \multirow{3}{*}{\multicolumn{2}{|c|}{$\begin{array}{l}\text { 4. Title and Subtitle } \\
\text { Microstrip Antenna Array with Parasitic Elements }\end{array}$}} & 5. Report Date \\
\hline & & \\
\hline & & $\begin{array}{l}\text { 6. Performing Organization Code } \\
506-58-22\end{array}$ \\
\hline \multirow{3}{*}{\multicolumn{2}{|c|}{$\begin{array}{l}\text { 7. Author(s) } \\
\text { Kai F. Lee, Roberto J. Acosta, and } \\
\text { Richard Q. Lee }\end{array}$}} & 8. Performing Organization Report No. \\
\hline & & $E-3615$ \\
\hline & & 10. Work Unit No. \\
\hline \\
\hline \multicolumn{2}{|c|}{$\begin{array}{l}\text { National Aeronautics and Space Administration } \\
\text { Lewis Research Center } \\
\text { Cleveland, Ohio } 44135\end{array}$} & 11. Contract or Grant No. \\
\hline \multicolumn{2}{|l|}{ 12. Sponsoring Agency Name and Address } & Technical Memorandum \\
\hline \multicolumn{2}{|c|}{$\begin{array}{l}\text { National Aeronautics and Space Administration } \\
\text { Wasinington, D.C. } 20546\end{array}$} & 14. Sponsoring Agency Code \\
\hline \multicolumn{3}{|c|}{$\begin{array}{l}\text { 15. Supplementary Notes } \\
\text { Prepared for the } 1987 \text { AP-S International Symposium sponsored by the Institute of } \\
\text { Electrical and Electronics Engineers, Blacksburg, Virginia, June 15-17, } 1987 \text {. } \\
\text { Kai F. Lee, Dept. of Electrical Engineering, The University of Akron, Akron, } \\
\text { Ohio } 44325 \text {; Roberto J. Acosta and Richard Q. Lee, NASA Lewis Research Center. }\end{array}$} \\
\hline \multicolumn{3}{|c|}{$\begin{array}{l}\text { 16. Abstract } \\
\text { This paper discusses the design of a large microstrip antenna array in terms of } \\
\text { subarrays consisting of one fed patch and several parasitic patches. The poten- } \\
\text { tial advantages of this design are discussed. Theoretical radiation patterns of } \\
\text { a subarray in the configuration of a cross are presented. }\end{array}$} \\
\hline \multicolumn{3}{|l|}{$\begin{array}{l}\text { 17. Key Words (Suggested by Author(s)) } \\
\text { Microstrip antennas } \\
\text { Antenna radiation patterns } \\
\text { Numerical analysis }\end{array}$} \\
\hline $\begin{array}{l}\text { 19. Security Classif. (of this report) } \\
\text { Unclass if ied }\end{array}$ & $\begin{array}{l}\text { 0. Security Classif. (of this page) } \\
\text { Unc lassified }\end{array}$ & $\begin{array}{c}21 . \text { No. of pages } \\
5\end{array}$ \\
\hline
\end{tabular}

*For sale by the National Technical Information Service, Springfield, Virginia 22161 